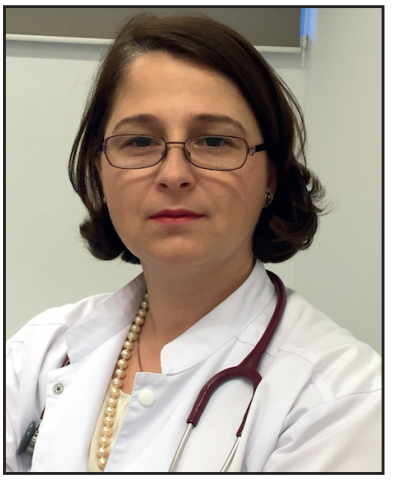

Camelia C. DIACONU凶

International Secretary General of the Balkan Medical Union

President of the Romanian National Section

Secrétaire Général International de l'Union Médicale Balkanique

Présidente de la Section Nationale Roumaine

\section{VACCINES: BETWEEN BENEFITS AND CONCERNS}

The evolution of medicine is strongly related to technological progresses and to vaccines that increased the life expectancy during the last century. The appearance of vaccines represented a true revolution in medicine. The principle of vaccination has been stated by Louis Pasteur in 1881 and is very simple: the exposure to an attenuated form of the disease to prevent a more severe form. Pasteur has discovered the first attenuated artificial vaccine, represented not by a microorganism similar to that causing the disease, but from the same strain having lost its virulence.

The history of vaccination begins in the $18^{\text {th }}$ century, with the monography of Edward Jenner, but there are cases in history that prepared the development of preventive medicine. Mithridates, the king of Pontus, conquered by Romans, wanted to suicide by ingestion of poison. His two daughters died after drinking the poison, but Mithridates survived and asked one of his people to kill him with a sword. His survival after poisoning was linked to the daily usage of certain drugs, which protected him against an otherwise deadly dose of poison. This legend explains the biological phenomenon of habituation by ingestion of progressive doses of poison. Since historical times, it is known that certain infectious diseases (like plague) can not appear twice in humans.

The discovery of vaccines led to important changes of public health policies. In 1908, Bacille

\section{VACCINS: ENTRE AVANTAGES ET PRÉOCCUPATIONS}

L'évolution de la médecine est fortement liée aux progrès technologiques et aux vaccins qui ont augmenté l'espérance de vie au cours du siècle dernier. L'apparition des vaccins a représenté une véritable révolution en médecine. Le principe de la vaccination a été énoncé par Louis Pasteur en 1881 et est très simple: l'exposition à une forme atténuée de la maladie pour éviter une forme plus sévère. Pasteur a découvert le premier vaccin artificiel atténué, représenté non pas par un microorganisme similaire à celui causant la maladie, mais à partir de la même souche ayant perdu sa virulence.

L'histoire de la vaccination commences au XVIIIe siècle, avec la monographie d'Edward Jenner, mais il y a des cas dans l'histoire qui ont préparé le développement de la médecine préventive. Mithridate, le roi de Pont, conquis par les Romains, voulait se suicider par ingestion de poison. Ses deux filles sont mortes après avoir bu le poison, mais Mithridate a survécu et a demandé à l'un de ses hommes de le tuer avec un couteau. Sa survie après un empoisonnement était liée à l'utilisation quotidienne de certaines substances, ce qui le protégeait contre une dose autrement mortelle du poison. Cette légende explique le phénomène biologique de l'accoutumance par ingestion de doses progressives de poison. Depuis les temps historiques, on sait que certaines maladies infectieuses (comme la peste) ne peuvent pas survenir deux fois chez l'homme. 
de Calmette et Guerin (BCG) was discovered, as consequence of accumulated knowledge on tuberculosis. Once the safety of BCG and its protective effects have been demonstrated in animals, human vaccination against tuberculosis was imposed after the First World War, when tuberculosis was responsible for $20-40 \%$ of deaths. Nowadays, tuberculosis is still an important public health issue in developing countries, with an increasing number of cases also in developed countries, explained mainly by the multi-resistance to antibiotics. The BCG vaccination remains an effective preventive measure, inexpensive, and with limited side effects.

The flu has been known since ancient times and it is caused by an RNA virus. In the $14^{\text {th }}$ century it was called influenza. Influenza can be epidemic or pandemic. Epidemic influenza occurs every year during winter, when more severe pandemic influenza occurs several times a century. The most severe influenza pandemic appeared in Spain, between 1918-1919, and was responsible for 50-100 million deaths worldwide, the most lethal health disaster of all time, comparable to the black plague between 1347-1350. Nowadays, the influenza vaccines can prevent the influenza pandemics.

During the last years, because the most severe epidemics have disappeared or are in course of disappearance, it is increasingly difficult to convince the population (especially from developed countries) about the necessity to get vaccinated against a risk that may be considered minor. Moreover, the fear of side effects, stimulated by a part of mass media, led to a decrease of vaccination rate, which explains the recent appearance of cases of measles or diphtheria.

Since their apparition, vaccines have been a matter of debate. The risks associated to vaccination are better accepted when the fear of a certain infectious disease is great. In this context, the role of mass media is very important, because when alarmist information regarding a certain vaccine is announced, a certain part of the population understand that it is better to refrain from getting the vaccine. Moreover, the anti-vaccines movement sustains that scientific publications concerning vaccinations are controlled by governments and pharmaceutical companies, who underestimate the side effects of vaccinations. The success of vaccination is based on a double confidence: confidence in the safety of the vaccine (guaranteed by doctors and governments) and confidence in the need for vaccination. To obtain this confidence, it is of utmost importance to intensify the mass education for health, by healthcare professionals who must educate and motivate the population.

COVID-19 pandemics put the entire world on pressure and fear. This new viral disease does not
La découverte de vaccins a conduit à d'importants changements dans les politiques de santé publique. En 1908, le Bacille de Calmette et Guérin (BCG) a été découvert par suite de l'accumulation des connaissances sur la tuberculose. Une fois que l'innocuité du BCG et de ses effets protecteurs ont été démontrés chez l'animal, la vaccination humaine contre la tuberculose a été imposée après la Première Guerre mondiale, lorsque la tuberculose était responsable de 20 à 40\% parmi les décès. En 1950, la vaccination BCG est devenue obligatoire pour toute la population. De nos jours, la tuberculose est toujours un problème de santé publique important dans les pays en développement, avec un nombre croissant de cas également dans les pays développés, expliquée principalement par la multirésistance aux antibiotiques. La vaccination BCG reste une mesure préventive efficace, peu coûteuse et avec des effets secondaires limités.

La grippe est connue depuis l'Antiquité et elle est causée par un virus à l'ARN. Au 14ème siècle, on l'appelait la grippe. La grippe peut être épidémique ou pandémique. Une épidémie de grippe survient chaque année pendant l'hiver, lorsque la grippe pandémique plus grave se produit plusieurs fois par siècle. La pandémie de grippe la plus grave est apparue en Espagne, entre 1918-1919, et a été responsable de 50 à 100 millions de morts dans le monde, la catastrophe sanitaire la plus meurtrière de tous les temps, comparable à la peste noire entre 1347 et 1350 . De nos jours, les vaccins antigrippaux peuvent prévenir les pandémies de grippe.

Au cours des dernières années, vu que les épidémies les plus sévères ont disparu ou sont en cours de disparition, il est de plus en plus difficile de convaincre la population (en particulier des pays développés) de la nécessité de se vacciner contre un risque qui peut être considéré comme mineur. De plus, la peur des effets secondaires, stimulée par une partie des médias de masse, a conduit à une baisse du taux de vaccination, ce qui explique l'apparition récente de cas de rougeole ou de diphtérie.

Depuis leur apparition, les vaccins font débat. Les risques associés à la vaccination sont mieux acceptés lorsque la peur d'une certaine maladie infectieuse est grande. Dans ce contexte, le rôle des médias de masse est très important, car lorsque des informations alarmistes concernant un certain vaccin sont annoncées, une certaine partie de la population comprend qu'il vaut mieux s'abstenir de se faire vacciner. De plus, le mouvement anti-vaccination soutient que les publications scientifiques concernant les vaccinations sont contrôlées par les gouvernements et les sociétés pharmaceutiques, qui sous-estiment les effets secondaires des vaccinations. Le succès de la vaccination repose sur une double confiance: la confiance 
have a specific treatment until now, only the current restrictions being able to prevent more people from being infected or dying. A vaccine could be the only solution to fight the pandemics and the best exit strategy, but the population needs to be properly informed and educated.

„No conflict of interest" dans la sécurité du vaccin (garantie par les médecins et les gouvernements) et la confiance dans la nécessité de la vaccination. Pour obtenir cette confiance, il est de la plus haute importance d'intensifier l'éducation de masse pour la santé, par des professionnels de santé qui doivent éduquer et motiver la population.

La pandémie de COVID-19 met le monde entier sous pression et peur. Cette nouvelle maladie virale n'a pas de traitement spécifique jusqu'à présent, seules les restrictions actuelles pouvant empêcher plus de personnes d'être infectées ou de mourir. Un vaccin pourrait être la seule solution pour lutter contre les pandémies et la meilleure stratégie de sortie, mais la population doit être correctement informée et éduquée. 